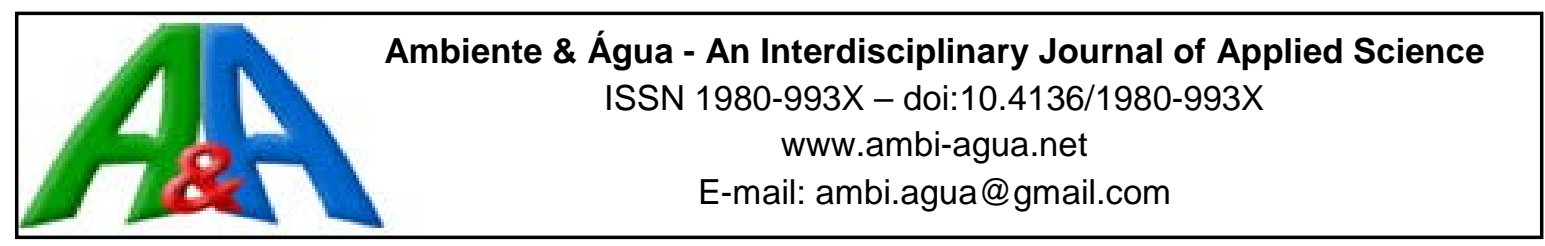

\title{
Efficacy of a solar still in destroying virus and indicator bacteria in water for human consumption
}

\author{
ARTICLES doi:10.4136/ambi-agua.2084
}

Received: 28 Jan. 2017; Accepted: 03 Jun. 2018

\author{
Felipe Tiago do Nascimento ${ }^{1 *}$; Carlos Augusto do Nascimento ${ }^{1}$; \\ Fernando Rosado Spilki²; Rodrigo Staggemeier²; Cláudio Marcos Lauer Júnior² \\ ${ }^{1}$ Universidade FEEVALE (FEEVALE), Novo Hamburgo, RS, Brasil \\ Instituto de Ciências Exatas e Tecnológicas (ICET). E-mail: eng.felipetn@gmail.com, \\ eng.carlosnascimento@gmail.com \\ ${ }^{2}$ Universidade FEEVALE (FEEVALE), Novo Hamburgo, RS, Brasil \\ Instituto de Ciências da Saúde (ICS). E-mail: fernadors@feevale.br, rstaggemeier@gmail.com, \\ claudiomarcos@feevale.br \\ *Corresponding author
}

\begin{abstract}
Natural water distillation can destroy and/or inactivate microorganisms that are sensitive to heat and ultraviolet radiation (UV). This method is currently used to provide fresh water in ships and in the desalination of brackish water. For the development of this research, a pilotscale solar still was built and installed in the southern region of Brazil, in order to assess its efficiency in water disinfection, which was based on the most probable number (MPN) of total coliforms and Escherichia coli, in addition to the DNA copy number of human adenovirus type 5 (HAdV-5) in raw, undistilled samples and in treated distilled water. Results showed that the distillation process removed 100\% of total coliform and Escherichia coli and $4.5 \log (99.997 \%)$ of HAdV-5, which meets the microbiological standards for drinking water according to national Brazilian regulations, as well as USEPA and HEALTH CANADA requirements.
\end{abstract}

Keywords: adenovirus, solar distillation, water disinfection.

\section{Eficácia de um destilador solar na desinfecção de vírus e bactérias indicadoras em água destinada ao consumo humano}

\section{RESUMO}

A destilação natural da água pode destruir e/ou inativar microorganismos que são sensíveis ao calor e a radiação ultravioleta (UV). Este método é utilizado, atualmente, para fornecer água potável em navios e para dessalinização de água salobra. Para o desenvolvimento desta pesquisa, um destilador solar em escala piloto foi construído e instalado na região sul do Brasil de forma a se verificar a eficiência do equipamento na desinfecção de água. A verificação de eficiência do equipamento foi baseada na determinação do número mais provável (NMP) de coliformes totais e Escherichia coli bem como no número de cópias de DNA do adenovírus humano tipo 5 (HAdV-5) em amostras de água antes e após a destilação. Os resultados demonstraram que houve $100 \%$ de remoção de coliformes totais e E. coli e 4,5 $\log (99,997 \%)$ de remoção de HAdV-5 após a destilação, o que está de acordo com o padrão microbiológico 
de potabilidade determinado pela legislação brasileira, pela USEPA e pela HEALTH CANADA.

Palavras-chave: adenovírus, desinfecção de água, destilação solar.

\section{INTRODUCTION}

According to the World Health Organization (WHO), every year there are around 2.5 billion cases of diarrhea among children in the world. Most of these cases are associated with the consumption of contaminated water, and result in the death of nearly 750,000 children under the age of five (5) (WHO and UNICEF, 2013). In addition, a quarter to a half of the cases of diarrhea reported annually can be prevented by improving water, sanitation and hygiene (Clasen et al., 2015). These diseases are usually caused by enteric pathogens, namely those associated with the fecal-oral transmission route, which are shed in the feces of infected individuals and transmitted to others through the consumption of contaminated water. Further, water may also carry pathogens of non-fecal origin which are released into the environment by wounds (PrüssÜstün et al., 2008).

The implementation of public water supply systems has ensured the delivery of safe drinking water to the population; however, there are very few water-quality monitoring programs relating to individual wells used by the rural population of Brazil. Thus, since many water sources commonly used in rural areas of the country, such as private wells, cisterns or reservoirs, are contaminated by pathogenic microorganisms, the risk of contamination by enteric pathogens in these locations is high. These contaminants must therefore be removed or inactivated in order to ensure the safety of these waters (Nogueira, 2003; Tchobanoglous et al., 2003; Alves et al., 2014).

Some of the bacteria responsible for causing diseases in humans are difficult to identify in water samples, due either to their presence in small amounts or to the cost and time needed to obtain results. Consequently, an indicator is usually used to test for the presence of pathogenic microorganisms, i.e., some sort of organism that can be quickly and easily found and which can indirectly indicate the presence of other organisms that are potentially disease-causing (Von Sperling, 2003; USEPA, 2006). Research for pathogens in waters intended for human consumption has for some time been restricted to assessing bacteria that serve as indicators for fecal contamination. The main reason for using coliform bacteria for this purpose is that it is released in large quantities through feces, 100 to 400 billion per day per person (Tchobanoglous et al., 2003). However, advances in concentration, detection and identification techniques of several types of viruses has enabled the assessment of viral contaminants in aquatic environments to be included within the framework of several studies (Wyn-Jones and Sellwood, 2001; Bosch et al., 2008; Fabres, et al., 2017).

It is known that viruses are the main cause of water-related diseases, and since the treatment techniques currently used do not ensure their complete removal or inactivation, they contaminate hydric resources on a large scale, becoming a serious health concern (Rodrigues et al., 2015). Although its role in transmitting diseases through water is less understood than those of bacteria and protozoa, it is known that the risk of viral infection is 10 to 10000 times greater (Bosch, 1998). Adenoviruses, in particular, are shed in high numbers in human feces and are also commonly found in sewers, polluted waters, water-harvesting sources for human consumption and even in drinking water around the world (Lee and Kim, 2002; AlbinanaGimenez et al., 2009; WHO, 2011). In addition to its host specificity, i.e., not having any particular animal source, its resistance to UV radiation is 60 times greater that of RNA viruses, making it possible to use these as a reliable indicator for systems that use UV radiation as 
disinfecting agent (Davison, 2003; Lechevallier and Au, 2004; Fong and Lipp, 2005; USEPA, 2007; WHO, 2011; Wong et al., 2012).

This research therefore assessed the efficacy of a pilot-scale solar still in removing total coliform bacteria and Escherichia coli, along with its removal and/or inactivation of adenovirus. The solar still inlet water samples (raw water) came from three different sources: two natural waters (from rooftop runoff and a small stream) and one water sample that had been artificially contaminated in laboratory. As far as the authors are aware, this is the first study to evaluate the disinfection of adenovirus in water for human consumption using solar stills.

\section{MATERIALS AND METHODS}

\subsection{Area of study}

The pilot-scale solar still was installed in the city of Taquara, RS, located $72 \mathrm{~km}$ from the

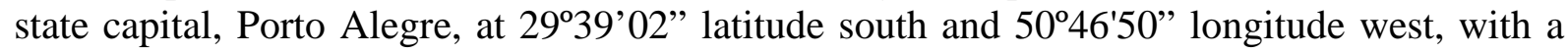
maximum altitude of 600 meters above sea level. The minimum annual temperature in the city is $4^{\circ} \mathrm{C}$ and the maximum is $37^{\circ} \mathrm{C}$, with an average of $23^{\circ} \mathrm{C}$, which makes it a mild climate (Taquara, 2013). The city is located on the middle sub-stretch of the Sinos River and is near to five rivers, namely Sinos, Padilha, Rio da Ilha, Paranhana and Rolante.

\subsection{Pilot scale equipment}

In this study, a symmetric double-slope solar still was built by the authors considering the geographic characteristics of the area where it was installed (Badran and Al-Hayek, 2004; Hashim et al., 2010; Saidur, 2011; Sharshir et al., 2016). With the aim of achieving greater productivity, the orientation of the chosen model was south-north, i.e., with the glass facing east-west (Figure 1), as studied by Abderachid and Abdenacer (2013).

With regard to the gradient of the cover (angle of inclination), Abdenacer and Nafila (2007) suggest this to be the same as the regional latitude of the installation location. Although for Rio Grande do Sul, Brazil this results in an average of $30^{\circ}$, in order to reduce the size of the equipment it was designed with a $25^{\circ}$ inclination. The basin has an external dimension of 836 x $836 \mathrm{~mm}$ and an internal dimension of 800 x 800 with side walls of $120 \mathrm{~mm}$ in height, which results in an approximate central height of $306 \mathrm{~mm}$ (calculated using trigonometry) (Figure 1).

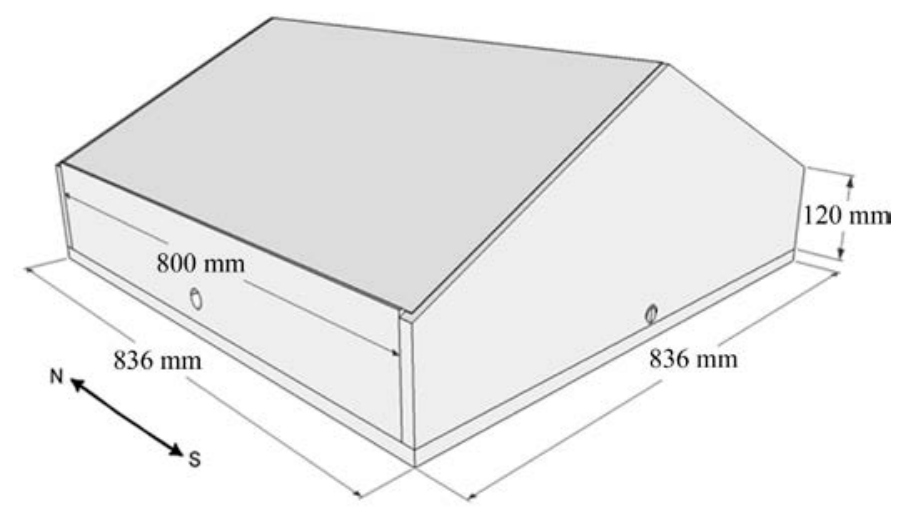

Figure 1. Isometric perspective of the pilot-scale solar still.

As shown in Figure 2, in order to provide support and rigidity to the structure, $18 \mathrm{~mm}$ thick MDF (medium-density fiberboard) was used due to the ease of working with this material, which also provides good thermal insulation. The basin had an inside area of $0.64 \mathrm{~m}^{2}$ and was painted black in order to increase its rate of absorbance, as suggested by Badran (2007). The

\section{IPABH}

Rev. Ambient. Água vol. 13 n. 4, e2084 - Taubaté 2018 
impermeability of the internal side (base and walls) was accomplished using FRP (Fiberreinforced plastic), commonly known as fiberglass, used in the construction of drinking water reservoirs, and for the cover a $4 \mathrm{~mm}$ glass plate was used.

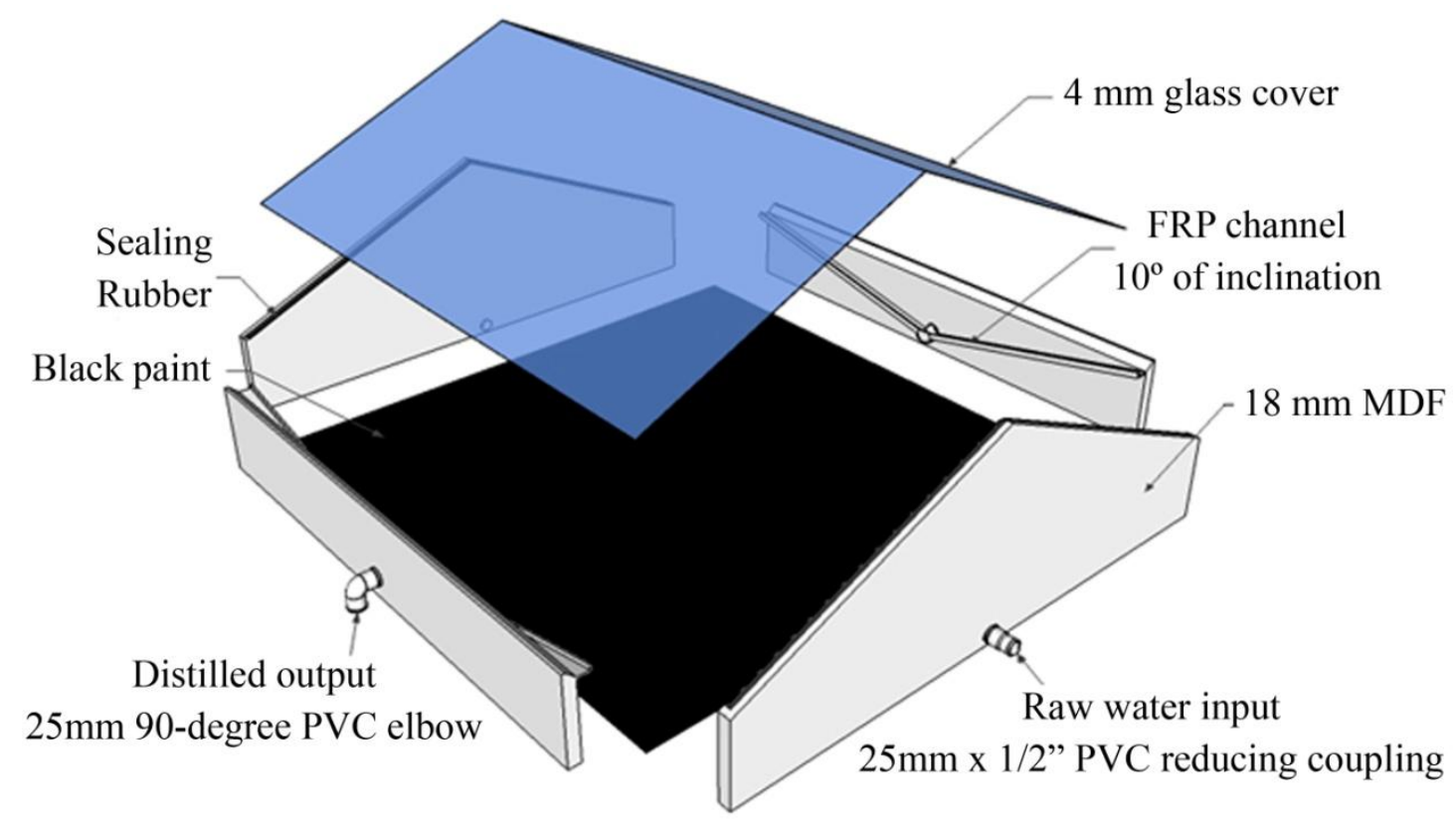

Figure 2. Exploded view of the solar still and materials description.

\subsection{Disinfection efficacy}

In order to assess the system's efficacy in disinfecting contaminated waters, total coliform bacteria, Escherichia coli and human adenovirus type 5 (HAdV-5) were used as indicators.

Prior to the start of each test, the equipment was washed using Extran ${ }^{\circledR}$ detergent and water from a public supply. Five liters of contaminated water were then placed in the raw water basin of the still, resulting in an initial $8 \mathrm{~mm}$ water depth. The tests were carried out from 8:00h to 15:00h, and the water distilled in the first hour was discarded in order to avoid possible contamination by the water used to wash the equipment. Afterwards, at 15:00h, a sample of distilled water relating to the period (9:00h to $15: 00 \mathrm{~h}$ ) was collected for analyses ( $0.5 \mathrm{~L}$ for viruses and $0.1 \mathrm{~L}$ for coliform bacteria)

All samples tested were stored under refrigeration following collection and taken in Styrofoam boxes filled with ice to the Molecular Microbiology Laboratory of Feevale University, Brazil, where the experiments were carried out.

\subsubsection{Removal of total coliform and Escherichia coli}

The efficiency of removal of total coliform bacteria and $E$. coli was tested using the following samples:

- roof runoff of a rural residence, at coordinates $29^{\circ} 37^{\prime} 5.48^{\prime \prime} \mathrm{S}$ and $50^{\circ} 46^{\prime} 28.55^{\prime \prime} \mathrm{O}$;

- water from a small stream collected on the same property (naturally contaminated);

- artificially contaminated water (inoculated in laboratory);

For the artificially contaminated samples, a bacterial culture using Escherichia coli ATCC 25922 grown overnight in Tryptic Soy Broth at $37^{\circ} \mathrm{C}$ was prepared. Then, $15 \mathrm{~mL}$ of this medium was added to $5 \mathrm{~L}$ of the rainwater. 
All samples were tested for the presence of total coliform and E. coli using the Colilert ${ }^{\circledR}$ kit and following the manufacturer's methodology up to 24 hours following sampling (IDEXX, 2013).

\subsubsection{Disinfection of HAdV-5}

To evaluate the efficiency of the system in removing HAdV-5, a sample of roof runoff rainwater collected as stated earlier (previously tested negative for the virus under study) was contaminated in laboratory with a viral culture medium. Two 5-liter containers of water were contaminated with the same amount of HAdV-5; one was subjected to the solar still model and other remained as the control sample. After processing by the method of disinfection, both samples were subjected to the concentration process described below. Quantitation of genomic DNA copies in the control sample was considered the total quantity inoculated ( $2.53 \times 10^{10}$ DNA copies $\left.\mathrm{L}^{-1}\right)$, and was then compared to the treated sample. The removal efficiency was calculated based on the DNA copy number present in the sample, which were assayed by Real Time Polymerase Chain Reaction (qPCR) method.

\section{Sample preparation}

In order to artificially contaminate the raw water sample, the A549 cell line was used (A549 being epithelial cells derived from human lung carcinoma and permissive to most human adenoviruses). The culture was carried out in cell culture flasks $\left(75 \mathrm{~cm}^{2}\right)$, using as growth medium a minimum essential medium (MEM) with Eagle salts supplemented with $5 \%$ fetal bovine serum (FBS) CULTILAB, 1\% of antibiotics and fungicide (PSA Cultilab-penicillin $\mathrm{G} 100 \mathrm{U} / \mathrm{ml} / 100 \mathrm{~g}$ streptomycin sulfate/ml $/ 0.25 \mathrm{~g}$ amphotericin $\mathrm{B} / \mathrm{ml}$ ).

\section{Concentration}

The water samples were concentrated using an adsorption-elution method previously described by Katayama et al. (2002) with some modifications. The following concentration protocol was used: with the aid of a vacuum pump, $0.5 \mathrm{~L}$ of water sample was filtered through an HA-type cellulose membrane with pores measuring $0.45 \mu \mathrm{m}$, provided with a negative charge (Millipore). This water had its $\mathrm{pH}$ previously adjusted to between 4.5 and 5.5, and $\mathrm{MgCl}_{2}$ was added. The viral particles that by chance were present in the test samples were then adsorbed to the membrane. Next, $87.5 \mathrm{ml}$ of a $0.5 \mathrm{mM}$ of $\mathrm{H}_{2} \mathrm{SO}_{4}$ solution were filtered through the membrane decoupling major cations, followed by another $2.5 \mathrm{ml}$ of $1 \mathrm{mMNaOH}$ ( $\mathrm{pH} 10.5$-10.8) solution, filtered through the same membrane. The resulting filtrate was placed in a tube containing $12.5 \mu \mathrm{L}$ solution of $50 \mathrm{mM} \mathrm{H}_{2} \mathrm{SO}_{4}$ and $12.5 \mu \mathrm{L}$ of TE $100 \mathrm{X}$ concentrated buffer.

\section{DNA Extraction and qPCR}

The viral genomes present in the samples were extracted through the RTP® DNA/RNA Virus Mini Kit (Invitek) extraction kit. After the extraction of viral genomes, the samples were subjected to amplification procedures of the genome target fragment in a preserved region of the hexon gene of the AdV (VTB2-HAdVCf 5'-GAGACGTACTTCAGCCTGAAT-3'and VTB2-HAdVCr 5'-GATGAACCGCAGCGTCAA-3'). The polymerase chain reactions (qPCR) in real time were carried out in an IQ5 Bio-Rad (Biorad, USA) thermo-cycler using the MyiQ ${ }^{\mathrm{TM}} 2$ device Two-Colour Real-Time PCR Detection System with the iQ ${ }^{\mathrm{TM}} 5$ optical system software, Version 2.1. We used the commercial Platinun ${ }^{\circledR}$ SYBR ${ }^{\circledR}$ Green qPCRSupermixUDG (Invitrogen, USA) kit, following the manufacturer's recommended methodology. Each reaction was composed of a denaturation cycle at $95^{\circ} \mathrm{C}$ for $10 \mathrm{~min}$., followed by 40 cycles, composed of one step at $95^{\circ} \mathrm{C}$ for $20 \mathrm{~s}$, and a combined annealing/extension step at $55^{\circ} \mathrm{C}$ for 1 minute. The fluorescence data were collected during the annealing/extension step. After that, a denaturing curve was made to check the specificity of amplification products (melting step

\section{IPABH}

Rev. Ambient. Água vol. 13 n. 4, e2084 - Taubaté 2018 
between 55 and $95^{\circ} \mathrm{C}$ ). Melting curve analysis was done using High Resolution Melting electrophoresis (HRM) to verify PCR product specificity, each viral specie has a specific temperature (HAdV-5; $\left.86^{\circ} \mathrm{C}\right)$. For generating standard curves, 10 -fold serial dilutions of standard controls (HAdV type 5) from $10^{-1}$ to $10^{-5}$ were prepared, starting at $4.55 \times 10^{9}$ genome copies per reaction. Prototype viral strains from HAdV-5 were cultivated in A549. All standard controls and samples were run in duplicate in 96-well plates (MicroAmp Applied Biosystems). No template control (NTC) and negative control were used in each run to confirm that there was no contamination in the assay. Only the results from assays within the range of $\mathrm{E}=90-110 \%$, slope in the range of 3.2-3.4 and $\mathrm{R}_{2}=0.98-0.99$ were considered. All results were confirmed by checking the peaks obtained during the high resolution melting curve.

\section{RESULTS AND DISCUSSION}

The tests were carried out in October, when the monthly average daily global solar irradiation for the southeast Brazil is estimated in about $4.25 \mathrm{kWh} / \mathrm{m}^{2}$ dia by the physical solar model BRASIL-SR (INPE, 2017).

\subsection{Total coliform and Escherichia coli removal efficiency}

The results obtained using total coliform and Escherichia coli as indicators for determining the efficacy of the solar still in disinfecting contaminated waters from natural sources and for a sample contaminated in the laboratory are shown in Table 1.

Table 1. Results of disinfection tests using total coliform bacteria and Escherichia coli.

\begin{tabular}{lcccc}
\hline \multirow{2}{*}{ Sampling } & \multicolumn{2}{c}{ Total coliform bacteria (NMP/100mL) } & Escherichia coli (NMP/100mL) \\
\cline { 2 - 5 } & Raw & Distilled & Raw & Distilled \\
\hline Roof runoff & $>2419.6$ & $<1$ & 3 & $<1$ \\
Stream & $>2419.6$ & $<1$ & 365.4 & $<1$ \\
Inoculated in laboratory & $>24000$ & $<1$ & $>24000$ & $<1$ \\
\hline
\end{tabular}

The temperature of the water inside the still reached $63.8^{\circ} \mathrm{C}$ and $68.8^{\circ} \mathrm{C}$ on the days when both the rainwater and the water from the small stream were tested, respectively. On the test day with laboratory-inoculated water, the temperature exceeded $70^{\circ} \mathrm{C}$.

The number of total coliform and E. coli for all samples treated by the solar still were below the detection limit of the analytical method ( $<1$ NMP / 100mL), i.e., the system showed $100 \%$ efficiency in reducing the number of these microorganisms. In addition, the use of water inoculated in laboratory with a high amount of $E$. coli and the roof runoff rainwater with near zero contamination demonstrates that regardless the degree of contamination of raw water the system is capable of providing treated water within the microbiological standards required by the Brazilian Ministry of Health Ordinance 2914/2011. In particular, these results are important when considering the roof runoff intended for potable purposes, since up-to-date studies demonstrate that the use of rainwater in houses may contribute to reduce the impacts of water shortages in drinking water distribution systems in southern Brazil (Lopes et al., 2016).

Other studies report the removal of $100 \%$ of total and fecal coliform; however, this did not occur in all samples tested by the authors. Balladin et al. (1999) found contamination by total coliform bacteria in all their treated water samples and claimed that this was probably due to airborne bacteria. Hanson et al. (2004) found contamination in 8\% of their treated samples, in this case by fecal coliforms, and claimed that this may have occurred due to the formation of turbulence at the time of adding the raw water to the equipment, which caused tiny bubbles to project contaminated water onto the internal surface of the cover. 
Several authors explain that the inactivation efficiency is related to the disinfecting power of UV radiation and visible light, which form part of the solar spectrum, and to the temperature the water reaches during the process, in addition to asserting that the synergistic effect of temperature and visible light occurs closer to $50^{\circ} \mathrm{C}$ (Acra et al., 1984; Wegeling et al., 1994; PROSAB, 2001). Thus, in cases where contamination of distilled water was found, it is important to know at what hour of the day these contaminations occurred, or, in cases where the determination of coliform was made in one single daily sample, what was the operating time schedule of the equipment. However, the authors reporting contamination do not present this data (Balladin et al., 1999; Hanson et al., 2004).

Therefore, because this study was conducted during the daytime period, i.e., with a higher incidence of radiation ( $9 \mathrm{~h} 00$ to $15 \mathrm{~h} 00$ ), it is important to carry out more tests in order to check that the microorganism reduction efficiency is maintained under less favorable conditions, such as the nighttime period or on rainy days, i.e., when there is little or no radiation. This necessity was made evident by the results found by Rijal and Fujioka (2001), who demonstrate that a disinfection system based on the synergistic effect of solar radiation and temperature, for the purpose of disinfecting drinking water, suffered reduced efficiency on cloudy days. Further, the factors mentioned by Balladin et al. (1999) and Hanson et al. (2004) as having influenced the microbiological quality of treated water in their studies highlight the need for adequate operation and maintenance of the equipment in order to avoid any future failures.

Overall, raw water quality (regardless of its source) does not seem to have influenced the efficiency of the pilot system, since the samples used are from sources that often have different physical, chemical and microbiological characteristics (Nascimento and Naime, 2009; Gikas and Tsihrintzis, 2012; Lee et al., 2012). Nevertheless, more studies are required, to include physical and chemical analyses of the samples, in order to obtain a more reliable result.

Despite the proven efficiency of solar distillation in the disinfection of water intended for human consumption, given the national legislation in relation to microbiological parameters, there is a deterrent to the exclusive use of the method when using surface water as the feed water for the distiller, given that Ordinance 2914/2011 of the Brazilian Ministry of Health states that in such cases filtration is mandatory (Brasil, 2011). However, with 100\% removal of E. coli from water contaminated with more than 24000 MPN / $100 \mathrm{ml}$, the solar distillation technique is more efficient than slow filtration, which is suitable for $E$. coli values of up to 5000 MPN / 100mL (Di Bernardo et al., 1999; 2005). In addition, when using well water as a raw water source, maintaining a free residual chlorine content is required by law, that is, the addition of chlorine after solar distillation is required (Brasil, 2011).

\subsection{Virus removal efficiency}

A comparison between the DNA copy number of HAdV-5 present in the contaminated and treated samples is shown in the graph in Figure 3. Additionally, the red line indicates the delimitation of the minimum amount of removal / inactivation established by USEPA and Health Canada.

The artificially contaminated laboratory sample used to feed the solar still had $2.53 \times 10^{10}$ DNA copies $\mathrm{L}^{-1}$, which was reduced to $6.94 \times 10^{5}$ in the sample treated by the system, representing a reduction of 4.5 log and thus complying with the USEPA and Health Canada standards (Canada, 2012; USEPA, 1989). 


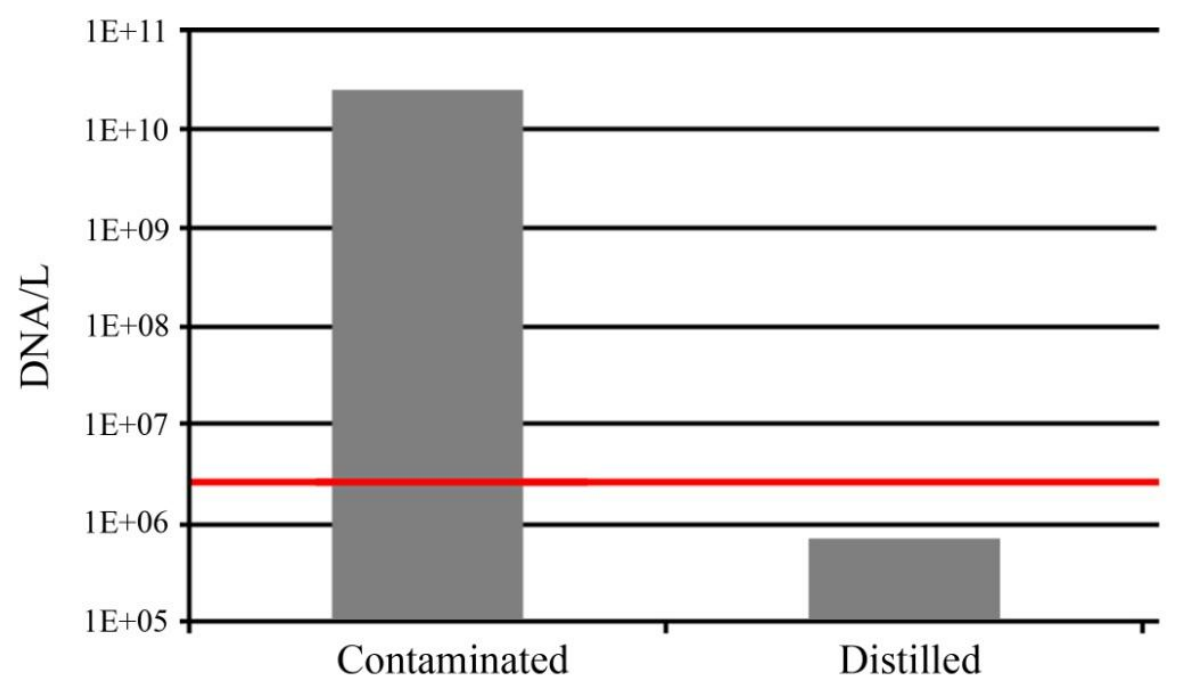

Figure 3. Results of DNA/L in contaminated and treated samples and USEPA and HEALTH CANADA disinfection standard.

This result represents the total number of genomic copies in the sample, i.e., originating from both virions as well as non-viable viral particles. However, high temperatures may damage the viral capsid or nucleic acids, preventing adsorption to the host cells or inactivating enzymes required for multiplication, causing the virus to lose its infection capacity, .i.e., the distillation process may have also inactivated the remaining viral load in the samples, which could be determined by plaque assay (Fong and Lipp, 2005). Using the pilot system of this study, on the removal/inactivation test day of $\mathrm{HAdV}-5$ the raw water exceeded $70^{\circ} \mathrm{C}$. It is therefore suggested that for future studies enzyme testing for viral integrity in the samples treated by the system be undertaken, in order to identify whether the DNA quantified by qPCR technique is associated to integral particles of HAdV or to free-viral DNA, whereby it is possible to find out whether these viruses are capable or not of infecting cells and possibly causing diseases (AlbinanaGimenez et al, 2009 ; Girones et al, 2010; Ruppach, 2014).

After temperature, UV irradiation is primarily responsible for the inactivation of viruses; however, despite their susceptibility to this aspect, viruses can be more resistant than bacteria, as evidenced by the results obtained. Furthermore, survival of the viruses in water environments may be significantly related to flagellate predators, extracellular protease, nuclease and other enzymes; therefore, it is convenient for studies on viruses inactivation using solar stills to be extended to other environmental water sources (Fong and Lipp, 2005)

The results obtained in this study show that the removal/inactivation efficiency of viruses by solar distillation is much greater than that of simple filtration and comparable to advanced treatment techniques, such as micro- and ultrafiltration membrane techniques (Madaeni et al., 1995; WHO, 2012). Currently, it is clear that multiple disinfection steps increase the reliability of a treatment system, i.e., a system comprising a single step of 4 logs inactivation/removal efficiency of a given pathogen is less reliable than one showing a two-step process with two logs each (Brasil, 2006; Ruppachi, 2014). Therefore, one factor that can be cited as a disadvantage when it comes to the use of solar distillation as a disinfection method regards its reliability, given that the process does not consist of multiple protection barriers, i.e., it needs only a simple failure to significantly compromise the quality of the water produced.

The development and improvement of inexpensive, alternative treatment technologies aimed at individual water supplies can lead to the reduction of contamination due to waterborne diseases, which, even with all current technological development, still occur in significant 
numbers. Among the non-conventional alternatives currently available, solar water distillation is a prominent method and can meet the demand for treated water in developing countries, small communities and rural properties that do not have access to a public water supply.

\section{CONCLUSION}

The removal efficiency of total coliform and Escherichia coli in all tests carried out was $100 \%$, regardless of the sample used to feed the system or its contamination level. This result is within drinking water's microbiological standards as established by the Brazilian Ministry of Health Ordinance 2914/2011. However, disinfection testing was not carried out neither during overnight periods, nor on rainy days. The removal of enteric viruses using HAdV-5 as an indicator was $4.5 \mathrm{log}$, which meets the USEPA and HEALTH CANADA regulations.

It is concluded that solar distillation is a simple, low-cost technique that is highly efficient in removing enteric pathogens from water intended for human consumption, with its efficacy comparable to more-expensive treatment methods. In addition, its use is recommended for rural properties or residential water-supply units that do not yet have access to a public drinking water supply. This will result in a significant reduction in contamination levels of waterborne diseases in these communities.

\section{REFERENCES}

ABDENACER, K.; NAFILA, S. Impact of temperature difference (water-solar collector) on solar-still global efficiency. Desalination, v. 209, p. 298-305, 2007.

ABDERACHID, T.; ABDENACER, K. Effect of orientation on the performance of a symmetric solar still with a double effect solar still (comparison study). Desalination, v. 329, p. 68-77, 2013.

ACRA, A.; RAFFOUL, Z.; KARAHAGOPIAN, Y. Solar disinfection of drinking water and oral rehydration solutions. Paris: UNICEF, 1984.

ALBINANA-GIMENEZ, N. et al. Analysis of adenoviruses and polyoma viruses quantified by qPCR as indicators of water quality in source and drinking-water treatment plants. Water Research, v. 43, p. 2011-2019, 2009.

ALVES, F. et al. Water quality and microbial diversity in cisterns from semiarid areas in Brazil. Journal of Water and Health, v. 12, n. 3, p. 513-525, 2014.

BADRAN, O. O. Experimental study of the enhancement parameters on a single slope solar still productivity. Desalination, v. 209, p. 136-143, 2007.

BADRAN, O. O.; AL-HAYEK, I. The effect of using different designs of solar stills on water distillation. Desalination, v. 169, p. 121-127, 2004.

BALLADIN, D. A.; HEADLEY, O.; ROACH, A. Evaluation of a concrete cascade solar still. Renewable Energy, v. 17, p. 191-206, 1999.

BOSCH, A. et al. New tools for the study and direct surveillance of viral pathogens in water. Current Opinion in Biotechnology, v. 19, p. 295-301, 2008.

BOSCH, A. Human enteric viruses in the water environment: a mini-review. International Microbiology, v. 1, p. 191-196, 1998.

BRASIL. Ministério da Saúde. Inspeção sanitária em abastecimento de água. Brasília, 2006.

\section{IPABH}

Rev. Ambient. Água vol. 13 n. 4, e2084 - Taubaté 2018 
BRASIL. Ministério da Saúde. Portaria n. 2914 de 12 de dezembro de 2011. Dispõe sobre os procedimentos de controle e de vigilância da qualidade da água para consumo humano e seu padrão de potabilidade. Diário Oficial [da] União, 14 dez. 2012.

CANADA. Health Canada. Guidelines for Canadian Drinking Water Quality-Summary Table. Ottawa, 2012.

CLASEN, T. F. et al. Interventions to improve water quality for preventing diarrhoea (Review). Cochrane Database of Systematic Reviews, n. 10, 2015.

DAVISON, A. J.; BENKO, M.; HARRACH, B. Genetic content and evolution of adenoviruses. Journal of General Virology, v. 84, p. 2895-2908, 2003.

DI BERNARDO, L.; DANTAS, Â. Di B. Métodos e técnicas de tratamento de água. 2. ed. São Carlos: RiMa, 2005.

DI BERNARDO, L.; BRANDÃO, C. C. S.; HELLER, L. Tratamento de águas de abastecimento por filtração em múltiplas etapas. São Carlos: ABES, 1999.

FABRES, R. B. et al. Evaluation of virus recovery methods and efficiency of tannin-derived coagulants in removing total coliforms, E. coli and enteric viruses in effluents of a domestic sewage treatment plant. Water Science and Technology, v. 76, p. 2195-2202, 2017.

FONG, T.; LIPP, E. K. Enteric Viruses of Humans and Animals in Aquatic Environments: Health Risks, Detection, and Potential Water Quality Assessment Tools. Microbiology and Molocular Biology Reviews, v. 69, n. 2, p. 357-371, 2005. http://dx.doi.org/10.1128/MMBR.69.2.357-371.2005

GIKAS, G. D.; TSIHRINTZIS, V. A. Assessment of water quality of first-flush roof runoff and harvested rainwater. Journal of Hydrology, n. 466-467, p. 115-126, 2012.

GIRONES, R. et al. Molecular detection of pathogens in water - the pros and cons of molecular techniques. Water Research, v. 44, p. 4325-4339, 2010.

HANSON, A. et al. Distillate water quality of a single-basin solar still: laboratory and field studies. Solar Energy, n. 76, p. 635-645, 2004.

HASHIM, A.Y.; AL-ASADI, J. M.; ALRAMDHAN, W. A. T. An attempt to solar still productivity optimization; solar still shape, glass cover inclination and inner surface area of a single basin solar still, optimization. Basrah Journal of Science, v. 28, n. 1, p. 3948, 2010.

IDEXX. Colilert. 2013. Available at: https://www.idexx.com/en/water/water-productsservices/quanti-tray-system/. Accessed: 28 Nov. 2013

INSTITUTO NACIONAL DE PESQUISAS ESPACIAIS - INPE. Atlas brasileiro de energia solar. 2. ed. São José dos Campos, 2017. 1 E-book.

KATAYAMA, H.; SHIMASAKi, A.; OHGAKI, S. Development of a Virus Concentration Method and its Application to Detection of Enterovirus and Norwalk Virus from Coastal Seawater. Applied Environmental Microbiology, v. 68, n. 3, p. 1033-1039, 2002.

LECHEVALLIER, M. W.; AU, K. Water treatment and pathogen control: Process efficiency in achieving safe drinking water. London: IWA Publishing, 2004. 
LEE, J. Y.; BAK, G.; HAN, M. Quality of roof-harvested rainwater - Comparison of different roofing materials. Environmental Pollution, v. 162, p. 422-429, 2012.

LEE, S.-H.; KIM, S.-J. Detection of infectious enteroviruses and adenoviruses in tap water in urban areas in Korea. Water Research, v. 36, p. 248-256, 2002.

LOPES, A. C.; RUPP, R. F.; GHISI, E. Assessment of the potential for potable water savings by using rainwater in houses in southern Brazil. Water Science \& Technology: Water Supply, v. 16, n. 2, p. 533-541, 2016.

MADAENI, S. S. et al. Virus removal from water and wastewater using membranes. Journal of Membrane Science, v. 102, p. 65-75, 1995.

NASCIMENTO, C. A.; NAIME, R. Panorama do uso, distribuição e contaminação das águas superficiais no Arroio Pampa na bacia do Rio dos Sinos. Estudos Tecnológicos, v. 5, n. 1, p. 101-120, 2009.

NOGUEIRA, G. et al. Microbiological quality of drinking water of urban and rural communities, Brazil. Rev. Saúde Pública, v. 37, p. 232-236, 2003.

PROSAB. Alternative disinfection processes and disinfectants in the production of drinking water. São Carlos: ABES, 2001.

PRÜSS-ÜSTÜN, A.et al. Safer water, better health: costs, benefits and sustainability of interventions to protect and promote health. Geneva: WHO, 2008.

RIJAL, G. K.; FUJIOKA, R. S. Synergistic effect of solar radiation and solar heating to disinfect drinking water sources. Water Science \& Technology, v. 43, n. 12, p. 155-162, 2001.

RODRIGUES, M. T. et al. Human adenovirus spread, rainfalls, and the occurrence of gastroenteritis cases in a Brazilian basin. Environmental Monitoring and, v. 187, p. 720, 2015.

RUPPACHI, H. Log10 Reduction Factors in Viral Clearance Studies. Bioprocessing Journal, v. 12, n. 4, p. 24-30, 2014.

SAIDUR, R. et al. An overview of different distillation methods for small scale applications. Renewable and Sustainable Energy Reviews, v. 15, p. 4756- 4764, 2011.

SHARSHIR, S. W. et al. Factors affecting solar stills productivity and improvement techniques: a detailed review. Applied Thermal Engineering, 2016.

TAQUARA. Webpage. Available at: http://www.taquara.com.br. Accessed on: 3 October 2013.

TCHOBANOGLOUS, G.; BURTON, F. L.; STENSEL, H. D. Wastewater Engineering: Treatment and Reuse. $4^{\text {th }}$ ed. Boston: McGraw-Hill, Metcalf \& Eddy, 2003.

UNITED STATES. Environmental Protect Agency - USEPA. Adenovirus Health and Criteria Document (Draft). Washington, 2007.

UNITED STATES. Environmental Protect Agency - USEPA. Ground Water Rule. Washington, 2006.

UNITED STATES. Environmental Protect Agency - USEPA. National Primary Drinking Water Regulations, Final Rule. Washington, 1989. 
VON SPERLING, M. Introdução à qualidade das águas e ao tratamento de esgotos. 2. ed., rev. Belo Horizonte: DESA - UFMG, 2003.

WEGELIN, M. et al. Solar water disinfection: scope of the process and analysis of radiation experiments. Aqua: Journal of Water Supply Research and Technology, v. 43, p. 154169, 1994.

WORLD HEALTH ORGANIZATION - WHO. A Manual for Economic Assessment of Drinking-Water Interventions. Geneva, 2012.

WORLD HEALTH ORGANIZATION - WHO. Guidelines for drinking-water quality. 4. ed. Geneva, 2011.

WORLD HEALTH ORGANIZATION - WHO; THE UNITED NATIONS CHILDREN'S FUND - UNICEF. Ending Preventable Child Deaths from Pneumonia and Diarrhoea by 2025 - The integrated Global Action Plan for Pneumonia and Diarrhoea (GAPPD). Paris, 2013.

WONG, K. et al. Application of enteric viruses for fecal pollution source tracking in environmental waters. Environment International, v. 45, p. 151-164, 2012.

WYN-JONES, A. P.; SELLWOOD, J. A review: Enteric viruses in the aquatic environment. Journal of Applied Microbiology, v. 91, p. 945-962, 2001. 